\title{
Mengembangkan Aspek Sosial/Kerjasama Siswa Melalui Metode Wisata TK Tirodeceng Pompanua Kabupaten Bone
}

\author{
Rukayah \\ Dinas Pendidikan Kabupaten Bone \\ Email: rukayah@gmail.com
}

\begin{abstract}
Abstrak. Penelitian ini bertujuan untuk mengetahui ketuntasan siswa dalam memahami materi bekerjasama siswa dan upaya meningkatkan hasil belajar bekerjasama siswa dengan menggunakan metode karyawisata. Penelitian ini termasuk jenis penelitian tindakan kelas. Pendekatan yang digunakan adalah pendekatan kualitatif. Subjek dalam penelitian ini adalah siswa TK Tirodeceng Pompanua tahun ajaran 2017/2018 yang berjumlah 17 orang. Objek dalam penelitian ini adalah penggunaan metode karyawisata dalam meningkatkan motivasi belajar kerjasama dan kreativitas murid. Alat yang digunakan untuk mengumpulkan data adalah test, wawancara dan observasi. Penelitian ini terdiri dari dua siklus. Upaya yang dilakukan untuk memahami materi kerjasama, peneliti memberikan pembelajaran secara berkelompok dengan menggunakan alat peraga yang disertai dengan demonstrasi. Pemberian tindakan dengan pembelajaran menggunakan metode karyawisata pada siklus I dan II diperoleh nilai rata-rata dan tingkat ketuntasan belajar murid. Pada tes awal nilai rata-rata murid 1,94, pada saat pos tes I nilai rata-rata murid meningkat menjadi 3.18 dan pada waktu pos tes II nilai rata-rata murid meningkat menjadi 3.23 dengan tingkat ketuntasan belajar sebesar $88 \%$. Berarti hasil yang diperoleh murid pada pos tes II sudah mencapai tingkat ketuntasan secara klasikal, yakni minimal 85\% murid yang memperoleh nilai $\geq$ bintang 3 .
\end{abstract}

Kata kunci: metode karyawisata, hasil belajar

\begin{abstract}
This study aims to determine the completeness of students in understanding the material in collaboration with students and efforts to improve learning outcomes in collaboration with students using the field trip method. This research is a type of classroom action research. The approach used is a qualitative approach. The subjects in this study were the students of TK Tirodeceng Pompanua in the 2017/2018 academic year, totaling 17 people. The object in this study is the use of field trips in increasing motivation to learn student cooperation and creativity. The tools used to collect data are tests, interviews, and observations. This study consisted of two cycles. Efforts are made to understand the material of collaboration, researchers provide learning in groups using teaching aids accompanied by demonstrations. Giving action by learning using the field trip method in the first and second cycles obtained the average value and level of student learning completeness. In the initial test, the students' average score was 1.94, when the test post I the student's average score increased to 3.18 and at the time of the test post-II the student's average score increased to 3.23 with a learning completeness level of $88 \%$. It means that the results obtained by
\end{abstract}


JIKAP PGSD: Jurnal Ilmiah Ilmu Kependidikan

students at the test post II have reached the level of completeness in a classical manner, namely at least $85 \%$ of students who get a value of $\geq 3$ stars.

Keywords: field trip methods, learning outcomes

\section{PENDAHULUAN}

Dalam rangka mencapai tujuan nasional, khususnya dalam bidang pendidikan, yang berupaya mencapai masyarakat adil dan makmur baik jasmani maupun rohani, perlu adanya usaha untuk menciptakan sumber daya manusia yang berkualitas, guna memenuhi kebutuhan pembangunan dewasa ini dan masa yang akan datang.

Berbicara tentang pendidikan berarti berbicara tentang manusia dengan segala aspeknya. Nilai suatu bangsa terletak dari kualitas sumber daya manusia yang menjadi warga Negara. Semakin baik kualitas manusianya, bangsa tersebut semakin memiliki peluang besar menuju kemajuan dan kemakmuran.

Untuk mencapai hal tersebut di atas, perlu ditumbuhkan motivasi yang kuat untuk meraih sesuatu yang dicita-citakan. Motivasi yang tumbuh baik secara internal maupun eksternal. Dengan motivasi yang kuat diharapkan dapat memacu meningkatkan kualitas dan potensi sumber daya manusia, khususnya prestasi dalam bidang pendidikan. Sebagaimana ditegaskan dalam pasal 4 UU No. 20 tahun 2003 tentang Sistem Pendidikan Nasional yang menyebutkan: 2 Pembangunan nasional di bidang pendidikan adalah mengembangkan potensi peserta didik agar menjadi manusia yang beriman dan bertaqwa kepada Tuhan yang Maha Esa, serta berakhlak mulia, sehat, berilmu, cakap, kreatif, mandiri, dan menjadi warga negara yang demoktratis serta bertanggung jawab.

Sumber daya manusia yang memiliki kecerdasan tinggi, yang ditunjang oleh adanya sikap dan prilaku yang bertaqwa terhadap Tuhan Yang Maha Esa, serta budi pekerti yang luhur, sangat diharapkan dalam rangka mencapai tujuan nasional. Di sisi lain adanya, pengetahuan dan keterampilan, serta pola kepribadian yang mantap dan dinamis, juga dapat membantu tercapainya tujuan nasional yaitu membentuk manusia-manusia bertanggung jawab terhadap pembangunan bangsa. Adapun langkah yang harus ditempuh dalam upaya membantu mewujudkan tujuan di atas adalah dengan menumbuhkan dan membina motivasi kepada para pelaku pendidikan, terutama motivasi para siswa yang merupakan harapan bangsa untuk memacu prestasi dalam segala bidang, agar menjadi generasi-generasi yang siap dalam menghadapi tantangan masa kini dan masa yang akan datang. Masih banyak siswa yang memiliki prestasi belajar yang rendah dan mengecewakan, hal tersebut diduga karena salah satu faktor penyebabnya adalah motivasi belajar mereka yang lemah dan tidak adanya rasa tanggung jawab Undang-undang RI No. 20 Tahun 2003 Tentang Sistem Pendidikan Nasional, (Jakarta: Kloang Klede, 2003) h. 13 terhadap pendidikan yang sedang mereka tempuh. Karena tidak adanya visi ke depan sebagai motivasi belajar untuk mempersiapkan diri menghadapi kehidupan di masa yang akan datang.

Untuk mencapai prestasi belajar yang maksimal, perlu adanya motivasi yang kuat yang ditumbuhkan oleh peserta didik, terutama oleh guru yang sebagai pengajar, agar para siswa selalu terdorong untuk mengembangkan potensi yang ada pada diri mereka.

Dalam metodik khusus Pendidikan, terdapat lima macam faktor-faktor pendidikan, dimana faktor yang satu dengan yang lainnya mempunyai hubungan yang erat.

Adapun kelima faktor tersebut yaitu:

1. Anak didik

2. Pendidik

3. Tujuan pendidikan

4. Alat-alat pendidikan

5. Milleu/lingkungan.

Dari kelima faktor-faktor tersebut antara yang satu dengan yang lain sangat erat hubungannya. Kesemuanya menentukan berhasil atau tidaknya tujuan pendidikan yang dilaksanakan. Dengan demikian, jika salah satu faktor tersebut tidak saling melengkapi, maka proses belajar mengajar tidak akan berjalan secara efektif. Oleh sebab itu, kelima faktor pendidikan tersebut dalam proses belajar harus ada. 
Vol,3. No,2. Tahun 2019

Di sisi lain dalam diri para peserta didik terdapat kepribadian-kepribadian yang unik dan pasti berbeda satu sama lainnya yang semestinya dapat lebih dikembangkan berubah ketika peserta didik dijadikan obyek pendidikan dan hanya diharuskan tiga D (duduk, diam, dengar) di dalam kelas. Padahal sesungguhnya mereka adalah makhluk unik yang termulia yang Allah ciptakan dengan berbekalkan akal pikiran. Seyogyanya proses belajar mengajar jadi lebih hidup sebab ketika manusia berpikir maka merupakan cerminan jiwa dan gambaran kehidupan serta eksistensi kehidupan itu sendiri. Dengan berpikir seperti itu maka sesungguhnya mereka telah memanusiakan manusia, ungkapan ini menggambarkan bahwa sesungguhnya banyak orang yang belum memperlakukan manusia secara manusiawi, maka manusia perlu dimanusiakan lagi agar pendidikan menjadi sebuah kualitas.

Ciri pengajaran yang berhasil salah satu diantaranya dilihat dari kadar kegiatan siswa belajar. Makin tinggi kegiatan belajar siswa makin tinggi pula peluang berhasilnya pengajaran. Keaktifan siswa belajar sangat diperlukan baik didalam maupun di luar kelas, menurut Alipandie, tanpa aktivitas belajar, pengajaran tidak akan memberikan hasil yang baik. Keberhasilan siswa belajar itu tidak hanya sekedar berhasil belajar, tetapi keberhasilan yang ditempuhnya dengan belajar aktif. Belajar dengan aktif dapat menyebabkan ingatan kita mengenai yang kita pelajari itu lebih lama dan pengetahuan kita menjadi lebih luas dibandingkan dengan belajar pasif. Guru yang profesional akan mampu memberikan motivasi bagi anak didiknya dalam proses belajar mengajar. Peningkatan motivasi belajar tersebut dapat dilakukan salah satunya melalui metode wisata. Metode ini dapat digunakan dalam kegiatan belajar mengajar untuk memberikan suasana baru bagi anak didik. Hal ini diterapkan karena untuk mengaplikasikan pelajaran yang didapat oleh siswa dalam kelas ke alam bebas terbuka. Kegiatan belajar siswa melalui metode ini akan mendorong siswa agar lebih mencintai alam semesta yang ia pijak serta menemukan konsep-konsep pokok dari suatu materi pembelajaran dan mencoba memikirkan hubungan antara manusia sebagai makhluk hidup dengan lingkungan sekitarnya.

\section{METODE PENELITIAN}

Jenis penelitian ini adalah penelitian tindakan kelas (Classroom Action Research). Pendekatan yang digunakan adalah pendekatan kualitatif yang berguna untuk mengungkapkan kesulitan belajar siswa dalam mempelajari materi bekerjasama siswa serta cara untuk mengatasi kesulitan-kesulitan tersebut sebagai upaya atau usaha dalam meningkatkan hasil belajar siswa.

Subjek Penelitian dalam PTK ini adalah siswa TK Tirodeceng Pompanua Kabupaten Bone.dengan jumlah siswa sebanyak 17 orang pada semester ganjil tahun pelajaran 2017/2018. Waktu penelitian dilaksanakan selama 6 bulan (mulai bulan Mei sampai dengan bulan Oktober 2017). Adapaun tempat penelitian ini dilaksanakan di TK Tirodeceng Pompanua Kabupaten Bone.

Operasionalisasi Variabel pada penelitian ini terdiri dari variabel bebas dan terikat. Variabel bebas dalam penelitian ini adalah pengajaran dengan menggunakan metode wisata dengan menggunakan tempat rekreasi sebagai media. Sedangkan, variabel terikat dalam penelitian ini adalah hasil belajar siswa pada materi pengembangan aspek sosial/bekerjasama siswa.

Penelitian ini terdiri dari dua siklus. Tiap siklus dilaksanakan sesuai dengan adanya perubahan yang ingin dicapai. Adapun langkahlangkah yang akan peneliti laksanakan yaitu:

1. Pembelajaran dilaksanakan dengan menggunkan metode wisata, khususnya membelajarkan materi bekerjasama siswa dimana guru bertindak sebagai pengajar, fasilitator, dan motivator.

2. Selama proses belajar mengajar berlangsung, peneliti dan teman sejawat bertindak sebagai observer/ pengamat.

3. Observasi dilaksanakan pada saat pembelajaran berlangsung untuk melihat kelebihan dan kekurangan metode wisata.

4. Setelah proses belajar mengajar selesai dilaksanakan maka diadakan wawancara kepada siswa.

5. Untuk mengetahui ketuntasan belajar siswa, maka diadakan tes hasil belajar siswa mengenai materi yang disediakan.

Secara umum penelitian tindakan kelas memiliki desain dengan empat langkah utama, yaitu perencanaan, tindakan, observasi, evaluasi, dan refleksi (Arikunto, 2008:16). 
Pengumpulan data dilaksanakan melalui tahapan tes, wawancara, dan observasi terhadap kelas/siswa yang menjadi subyek penelitian. Adapaun analisis data pada penelitian ini dilakukan melalui tiga tahap yaitu reduksi data, paparan data dan penyimpulan data (Jadmiko: 2003).

1. Reduksi data

Proses reduksi data dilakukan dengan menyeleksi, menyederhanakan, dan mentransformasikan data yang telah disajikan dalam transkrip catatan lapangan. Kegiatan reduksi data ini bertujuan untuk melihat kesalahan jawaban siswa dalam menyelesaikan soal-soal tentang bekerjasama siswa dan tindakan apa yang dilakukan untuk perbaikan kesalahan tersebut.

2. Paparan data

Paparan data adalah proses penampilan data secara sederhana dalam tabel frekuensi ataupun grafik, dan sebagainya.

3. Penyimpulan data

Penyimpulan data adalah proses pengambilan intisari dari data yang sudah terorganisasikan tersebut dalam bentuk pernyataan kalimat atau formula yang singkat dan padat tetapi mengandung pengertian yang luas. Penarikan kesimpulan untuk mengetahui persentase kemampuan siswa sebagai hasil pengukuran ketuntasan kompetensi siswa yang telah ditetapkan oleh TK Tirodeceng Pompanua Adapun rumus yang digunakan di dalam ketuntasan belajar adalah sebagai berikut :

1. Ketuntasan secara individu

Rumus persentase:

$\frac{\text { Jumlah skor yang diperoleh }}{\text { Jumlah skor maksimal }} \times 100 \%$

2. Ketuntasan secara klasikal

Rumus persentase ketuntasan :

$\frac{\text { Jumlah skor yang diperoleh }}{\text { Jumlah skor maksimal }} \times 100 \%$

Ketuntasan belajar individu dinyatakan tuntas apabila tingkat persentase ketuntasan minimal mencapai $65 \%$, sedangkan untuk tingkat klasikal minimal mencapai $85 \%$. Sedangkan, indikator keberhasilan penelitian ini adalah apabila instrumen-instrumen yang telah disiapkan pada tiap-tiap siklus dapat dilaksanakan dengan baik, aktivitas dan hasil belajar siswa meningkat, lebih dari $85 \%$ siswa yang mendapat nilai $\geq$ bintang 3 .

\section{HASIL DAN PEMBAHASAN}

Hasil penelitian dalam penelitian tindakan kelas ini dibedakan dalam tiga kegiatan, yaitu (1) pra tindakan, (2) siklus I, dan (3) siklus II.

Kegiatan pra tindakan yang dilakukan pada murid kelompok A TK Tirodeceng Pompanua menemukan permasalahan yaitu motivasi belajar siswa rendah, sebagaimana ditunjukkan dalam rekapitulasi hasil observasi terhadap sikap belajar siswa (lihat lampiran hasil observasi sikap siswa). Seiring dengan motivasi belajar siswa yang rendah, maka berdampak pula pada hasil belajar siswa yang rendah pula.

Dari tes awal yang dilakukan sebelumnya dapat diketahui bahwa skor dan nilai rata-rata siswa adalah 1,94. Hal ini menunjukkan bahwa tingkat penguasaaan siswa pada bekerjasama siswa masih rendah. Setelah mengetahui penguasaan siswa masih rendah peneliti membuat catatan mengenai kesulitan yang dialami siswa.

Berdasarkan hasil tes awal yang dikategorikan masih rendah atau masih mengalami kesulitan. Maka selanjutnya dilakukan pembelajaran dengan kegiatan pembelajaran dengan membawa siswa ke alam terbuka (taman bunga) dengan tujuan agar siswa dapat belajar sambil bermain. Setelah pembelajaran selesai maka dilakukan pos tes untuk mengetahui hasil belajar siswa. Dalam hal ini yang dinilai dari siswa adalah hasil pengamatan ketika di bawa berwisata. Siswa disuruh menceritakan hal-hal yang dilihat di tempat yang dikunjungi.

Hasil pos tes pada siklus I menunjukkan bahwa masih ada beberapa siswa yang memiliki nilai dibawah bintang 3. Nilai rata-rata pada saat pos tes I dari 17 siswa adalah 3.29. Namun demikian, jika dibandingkan dengan hasil perolehan nilai pada tes awal menunjukkan adanya peningkatan.

Untuk memperoleh hasil belajar yang lebih baik lagi, maka guru kelas kelompok B kembali melaksanakan perbaikan pembelajaran pada siklus II. Terutama pada pemberian motivasi kepada siswa. Demikian pula perencanaan pembelajaran dengan wisata lebih dimantapkan perencanaannya dan lebih banyak bimbingan kepada siswa. Setelah itu kembali mengadakan tes hasil belajar siklus II.

Berdasarkan data hasil pos tes pada siklus II diperoleh nilai rata-rata dari 17 siswa diperoleh 3.23. Hal ini menunjukkan adanya peningkatan 
hasil belajar siswa. Berdasarkan tabel diatas dapat diketahui bahwa nilai rata-rata siswa pada saat diadakan tes awal hanya rata-rata 1,94 dan siswa yang tuntas belajar adalah $36 \%$. Sedangkan saat pos tes pada siklus I dilaksanakan nilai rata-rata siswa meningkat menjadi 3.18 dan siswa yang tuntas belajar adalah $64.71 \%$. Kemudian pada pos tes siklus II nilai rata-rata siswa meningkat menjadi 3.23 dan siswa yang tuntas belajar adalah $88 \%$. Dengan demikian, dapat dinyatakan bahwa kemampuan siswa meningkat dalam memahami materi bercerita dengan metode pembelajaran wisata.

Ciri khas penelitian tindakan kelas adalah adanya siklus-siklus. Pada penelitian ini peneliti menjalankan dua siklus untuk mencapai hasil yang diinginkan.

\section{Siklus I}

a. Rencana (Planning)

Dalam penelitian ini kegiatan awal yang dilakukan peneliti adalah konsultasi dengan guru TK Tirodeceng Pompanua dan menyusun rencana pelaksanaan pembelajaran dengan metode berwisata. Setelah itu peneliti membuat program wisata, mulai lokasi yang akan dikunjungi sampai pada aspek keamanan siswa. Kemudian peneliti membuat lembar kerja siswa sebagai alat untuk mengumpulkan data tentang hasil belajar siswa.

b. Tindakan (Action)

Sebelum berwisata peneliti dan guru kelas TK Tirodeceng Pompanua terlebih dahulu melaksanakan tes awal untuk mengetahui pengetahuan awal siswa. Setelah itu pembelajaran dimulai dengan mengenalkan alat peraga yang digunakan dan peraturan dalam berdarmawisata/ berekreasi. Guru kelas TK menyampaikan kepada siswa bahwa materi yang akan dipelajari yaitu bekerja sama siswa, dan siswa akan bercerita sesuai yang disaksikan. Setelah itu guru menjelaskan materi bekerjasama siswa melalui metode wisata. Kemudian peneliti dan guru kelas memberikan lembar kerja anak serta bahan-bahan untuk alat peraga kepada siswa yang telah dibagi dalam 5 kelompok. Guru berkeliling memantau dan membimbing siswa serta memberikan penjelasan bagi kelompok yang belum paham atau kelompok yang mengalami kesulitan.

c. Observasi (Obsevation)

Observasi dilaksanakan oleh peneliti sendiri pada saat proses pembelajaran berlangsung. Observasi dilakukan untuk melihat aktivitas siswa dalam menggunakan alat peraga dan demonstrasi kerjasama siswa.

d. Refleksi (Reflection)

Pada akhir siklus diadakan refleksi terhadap hasil-hasil yang diperoleh siswa melalui kegiatan karyawisata untuk melihat bekerjasama siswa dan selanjutnya dilakukan pos tes untuk mengetahui penguasaan siswa mengenai materi pokok bekerjasama siswa pada di kelas TK Tirodeceng Pompanua. Dari hasil refleksi ini dapat diketahui peningkatan hasil belajar siswa dari tes awal ke siklus I.

\section{Siklus II}

a. Rencana (Planning)

Perolehan nilai siswa yang diperoleh pada siklus I terdapat beberapa siswa yang memiliki nilai masih dibawah 3 . Hal ini menunjukkan bahwa siswa masih kurang memahami materi bekerjasama siswa. Dengan demikian peneliti dan guru TK kembali melakukan pembelajaran melalui siklus II dengan lebih memfokuskan pada penyelesaian tugas-tugas yang berhubungan dengan tes yang diberikan agar tercapai target yang diinginkan.

b. Tindakan (Action)

Pembelajaran dengan kegiatan berwisata yang telah disusun oleh peneliti dan guru kelas diharapkan dapat meningkatkan hasil belajar siswa. Melalui kegiatan ini siswa lebih difokuskan untuk dapat menyelesaikan soal-soal yang telah diberikan.

c. Observasi (Observation)

Pada kegiatan belajar mengajar terlihat aktivitas siswa meningkat khususnya dalam menyelesaikan soal-soal tentang kegiatan rekreasi atau wisata.

\section{d. Refleksi (Reflection)}

Setelah pelaksanaan pembelajaran pada siklus II berakhir, peneliti dan guru kelas kembali melakukan pos tes I untuk mengetahui penguasaan siswa.

Setelah dilakukan pembelajaran pada siklus II dan pos tes II diperoleh peningkatan motivasi dan hasil belajar siswa TK Tirodeceng Pompanua pada materi bekerjasama siswa pada pembelajaran melalui metode wisata. Dengan adanya peningkatan nilai rata-rata siswa dari pos tes I ke pos tes II sebesar 3.23 dan juga sekaligus 
menandakan bahwa tidak perlu lagi dilaksanakan perbaikan pembelajaran.

Untuk kejelasan gambaran perkembangan/ peningkatan motivasi dan hasil belajar siswa dari tes awal ke siklus I dan II dapat dilihat pada gambar diagram berikut:

1. Nilai Rata-rata:

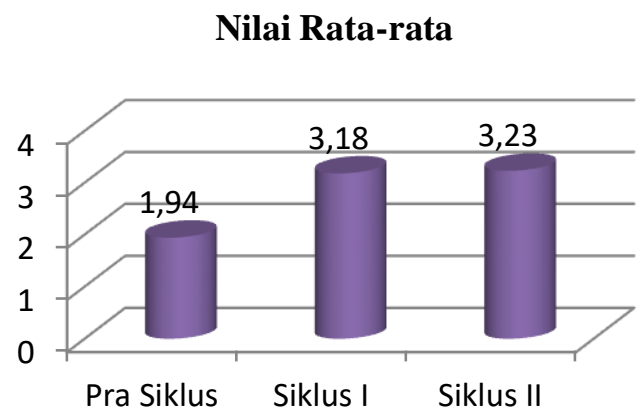

Tabel 4.6 Perkembangan motivasi/sikap belajar siswa

\begin{tabular}{c|c|c|c|c|c|c}
\multirow{2}{*}{ Kategori } & \multicolumn{2}{|c|}{ Pra Siklus } & \multicolumn{2}{c|}{ Siklus I } & \multicolumn{2}{c}{ Siklus II } \\
\cline { 2 - 7 } & Frekuensi & $\%$ & Frekuensi & $\%$ & Frekuensi & $\%$ \\
\hline Sangat senang & 2 & 11.76 & 6 & 35.29 & 7 & 41.17 \\
Senang & 4 & 23.53 & 5 & 29.41 & 8 & 47.05 \\
Kurang senang & 4 & 23.53 & 3 & 17.65 & 1 & 5.90 \\
Tidak senang & 7 & 41.18 & 3 & 17.65 & 1 & 5.90 \\
\hline Jumlah & 17 & 100 & 17 & 100 & 17 & 100
\end{tabular}

Berdasarkan data tersebut dari tes awal, pos tes I dan pos tes II menunjukkan adanya peningkatan motivasi dan hasil belajar siswa. Peningkatan motivasi/sikap belajar siswa pada pra siklus sangat senang/senang frekuensinya 6 atau $35.29 \%$, siklus I sebesar 11 atau $64.70 \%$, dan pada siklus II meningkat menjadi 15 atau $88.23 \%$. Sedangkan nilai rata-rata siswa pada tes awal 1.94 (36\%), pos tes I sebesar 3,18 (65\%) dan pos tes II $3.23(88 \%)$. Dengan demikian dapat dinyatakan bahwa pembelajaran melalui metode wisata dapat meningkatkan motivasi dan hasil belajar siswa TK Tirodeceng Pompanua Kabupaten Bone semester ganjil Tahun Pelajaran 2017/2018.

\section{SIMPULAN DAN SARAN}

Berdasarkan penelitian yang disajikan dalam BAB IV dapat diambil kesimpulan bahwa:

1. Pembelajaran dengan menggunakan metode wisata dapat meningkatkan hasil motivasi dan bekerjasama siswa.

2. Dari hasil pelaksanaan siklus I diperoleh tingkat ketuntasan belajar sebesar $65 \%$.
2. Ketuntasan Belajar:

\section{Ketuntasan Belajar}

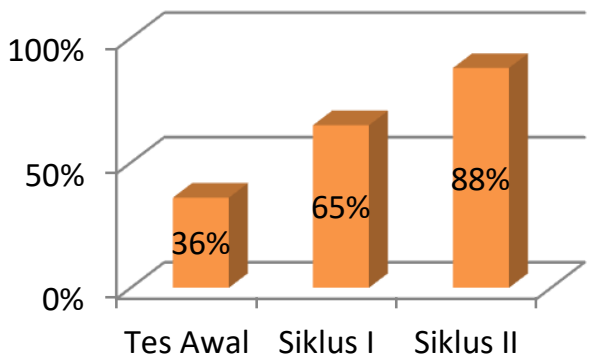

Kemudian untuk perkembangan motivasi/sikap belajar siswa dari pra siklus, Siklus I dan Siklus II dapat dilihat pada tabel berikut.
3. Dari hasil pelaksanaan siklus II diperoleh tingkat ketuntasan belajar sebesar $88 \%$.

Berdasarkan temuan penelitian yang telah disajikan pada BAB IV maka disarankan:

1. Bagi guru yang menerapkan pembelajaran dengan menggunakan metode wisata hendaknya lebih teliti dalam perencanaan pembelajaran, terutama kepada siswa TK, harus lebih sabar dan memperhatikan alokasi waktu yang ada.

2. Untuk membagi kelompok jangan hanya melihat dari nilainya saja, tetapi juga perhatikan kelakuan anak, sehingga bagi anak yang sering berulah tidak berada dalam satu kelompok.

3. Pada peneliti berikutnya, jika ingin melakukan jenis penelitian yang sama sebaiknya dilaksanakan lebih dari dua siklus, agar tecapai hasil yang lebih maksimal. 


\section{DAFTAR RUJUKAN}

Ahmadi, Abu, dkk. 2005. Strategi Belajar Mengajar. Bandung: Pustaka Setia

Agustina. 2006. Magic Mathic's I. Semarang: Penerbit ANDI.

Amin, Safwan. 2005. Pengantar Psikologi Pendidikan. Banda Aceh: PeNA.

Arikunto, Suharsimi, dkk. 2008. Penelitian Tindakan Kelas. Jakarta: BUMI AKSARA.

Dewi, Rosmala dan Irsan. 2003. Penelitian Tindakan Kelas. Fakultas Ilmu Pendidikan

Djamarah, S.B, dkk. 2006, Strategi Belajar Mengajar. Jakarta: Rineka Cipta

Enco, Mulyoso. 2007. Menjadi Guru Profesional. Bandung: PT. Remaja Rosdakarya.

Gordon, Thomas. 1990. Guru Yang Efektif. Jakarta: PT Raja Grafindo Persada.

Jadmiko, B. 2003. Penelitian Tindakan Kelas (PTK., Jakarta: Depdikbud.

Lask, Bryan. 1991. Memahami dan Mengatasi Masalah Anak Anda. Jakarta: PT Gramedia Pustaka Utama.

Malik, Fadjar. 2003. Undang-undang Sistem Pendidikan Nasional. Jakarta: Sinar Grafika.

Paimin dan Ekaningsih Joula. 1998. Agar Anak Pintar. Manado: Puspa Swara.

Rochiati, Wiriaatmadja. 2007. Metode Penelitian Tindakan Kelas. Bandung: Rosda.

Sardiman. 2003. Interaksi \& Motivasi Belajar Mengajar. Jakarta: Raja Grafindo Persada

Sugianto, Mayke. 1995. Bermain, mainan dan permainan. Jakarta: Departemen Pendidikan dan Kebudayaan.

Susianti, D.Y. 2008. Pembelajaran tematik sebagai upaya meningkatkan hasil belajar siswa kelas 2 SDN 034 Samarinda Ulu.

Suryosubroto. 2002. Proses Belajar Mengajar di Sekolah. Jakarta: Rineka Cipta 